\title{
5+1 Newspaper Organizer: A Classroom Strategy for Developing Students' Reading Skill
}

\author{
Nurlina, Supiani*, Iwan Perdana \\ Universitas Islam Kalimantan MAB Banjarmasin, Indonesia \\ *supiani.uniska@gmail.com
}

\begin{abstract}
The objectives of this study are to investigate the implementation of the $5+1$ Newspaper Organizer as a strategy in developing the students' reading skill and to find out the students' and teacher's responses when the 5+1 newspaper organizer strategy is implemented at the teaching and learning activities. The qualitative method is employed in this study in which the data are collected from observation, interview, and documentation at a junior high school in South Kalimantan province, Indonesia. The findings report that the use of 5+1 newspaper organizer contributed positively to students' reading skill because it helped them find main ideas, the meaning of words, and the explicit and implicit information of the text easily. They worked collaboratively by sharing ideas and learning texts together. They were also engaged with the strategy and felt happy, enthusiastic and active at the reading class because the teacher gave the students with more opportunity to work in group without feeling shy or doubt to learn it. Therefore, 5+1 Newspaper Organizer is an effective strategy for developing students' reading ability.
\end{abstract}

Keywords: classroom strategy; 5+1 newspaper organizer; reading skill; students' responses; teaching reading

\begin{abstract}
ABSTRAK
Tujuan penelitian ini adalah untuk menginvestigasi pada implimentasi strategi $5+1$ newspaper organizer dalam mengembangkan keterampilan membaca siswa and menemukan respons siswa dan guru ketika mengajarkan strategi tersebut di aktivitas pengajaran dan pembelajaran. Metode kualitatif digunakan dalam penelitian ini dengan pengumpulan data observasi, interview dan dokumentasi lainnya di salah satu sekolah menengah pertama negeri (SMPN) di provinsi Kalimantan Selatan, Indonesia. Penemuan penelitian ini melaporkan bahwa penggunaan strategi $5+1$ newspaper organizer berkontribusi secara positif terhadap keterampilan menulis siswa karena the strategi membantu mereka menemukan ide pokok, arti/makna kata, informasi teks secara eksplisit dan implisit secara mudah. Mereka belajar secara kolaboratif dengan berbagi ide satu sama lain dan mepelajari jenis teks secara bersama-sama. Mereka juga tertarik dengan strategi tersebut dan merasa senangat, anthusias dan aktif di kelas reading karena guru memberikan kesempatan kepada siswa untuk bekerja berkelompok tanpa rasa malu dan ragu untuk mempelajarinya. Oleh krena itu, 5+1 newspaper organizer adalah strategi efektif untuk mengembangkan keterampilan menulis siswa.
\end{abstract}

Kata Kunci: strategi kelas; 5+1 newspaper organizer; ketempilan membaca; respons sisswa; mengajar membaca

\section{Introduction}

English has been widely used around the globe as a means of communication. It is a global language which plays a crucial role for people in the world to convey and transfer their thought and ideas to other people. This language is very important as a tool of communication in other countries in the term of the growth of political and economic development (Crystal, 2003). The use of the English language is used in various purposes and scopes either in formal or informal sectors such as building good relationship in business, education and creating the international networks or links in the modern society today. Therefore, Indonesian is one of nonnative English countries has realized it and implemented a policy for very long time that English language as one of the compulsory subjects must be taught in the level of junior, senior high schools and university in order to prepare students to be able to interact in English fluently and compete in the globalization era. In Indonesia, teaching English 
language has been taught at every level from primary school to university. At the primary level, English is as optional level, but beginning from junior high school to university level, English is a compulsory subject that mandated by national Indonesian educational system (Yulia, 2014).

Reading is one of four English language skills that must be taught by teachers at schools. This skill is provided to prepare students' competence in understanding and comprehending a text (Barthimeus, 2011). In Indonesia the teaching of reading as a foreign language generally involves reading comprehension. This is because it purposes to improve students' reading skills who have been able to read well in their first language and in EFL, in understanding the meaning of an English text (Cahyono \& Widiati, 2006). Renandya argued that the main objective in teaching reading is to help learners find information from a reading passage. In the process of comprehending does not always emphasize on L2 students, the objectives of the course also involve teachers and their teaching strategies to teach some language aspects and comprehension-related skills to L2 students (2017).

Teaching reading is not easy because the researchers observed in the students of eighth grade in one of junior high schools, South Kalimantan province got difficulties to understand the meaning of the words or comprehend text information. They just read the text without knowing explicit and implicit information in the text. Moreover, they also did not know the main idea, generic structure of the text, and certain word reference. Those problems made the students' competence in reading low and as the result they got the low scores in doing the reading task.

Based on preliminary observation, the students did not have prior knowledge how to read English texts effectively and lacked of vocabulary. In addition, the teachers were not creative and innovative in teaching a reading skill and sometimes the teacher were so monotonous in teaching it, so those caused the students were not interested in learning reading skill. Barthimeus stated that the teacher who used traditional strategy in teaching reading could get bored in the teaching and learning process, and the students were not active (2011).

Therefore, the researchers try to solve the students' problems in teaching and learning reading by implementing $5+1$ Newspaper Organizer. This is one of reading strategies in teaching and developing students' reading skill and it is done in group, paired, or individual. The strategy of $5+1$ Newspaper Organizer refers to learning activities to classify, identify and summarize information systematically from print materials (Bellanca, 2007). The students can help students in learning a reading skill and give easiness for the students to find the information explicitly and implicitly in English texts by indicating WH questions: who, what, where, when, why and how (Bellanca, 2007).

\section{Research Method}

In this study, the researchers used a qualitative method to investigate the implementation of $5+1$ Newspaper Organizer as a classroom strategy for developing reading skills at the eighth grade students at one of junior high schools, South Kalimantan province. The participants in this study were an English teacher and twenty students. They were recruited voluntary to take part in the study to develop their readhing skill through the strategy.The data are taken from observation in which the researchers took notes and recorded the teaching and learning process at the classroom activities, interviewed an English teacher and some students to find their responses of using the strategy, and documented all the activities by taking some pictures at the classroom. However, taking the data is not easy because the researchers negotiated firstly to the principal of the school and the English teacher to get access in conducting the research. After getting permission, the researchers continued doing the research in some meetings at the class, then continued to interview to the English teacher and students. In the process of teaching and learning, the researchers took pictures as documents in the field. In analyzing the data, the researchers used the analysis phase that is described by Miles and Huberman in Sugiyono (2016:337) namely data reduction, data display, and drawing conclusion. 


\section{Results and Discussion}

1. Implementing 5+1 Newspaper Organizer as a Classroom Strategy for Developing Reading Skill

a. The First Meeting

The first meeting was held on Thursday 19th of July 2020 started from 11.05 until 12.25 a.m. The researchers observed the activities of English teacher in the process of learning English in the class VIII A. The teacher came to the class at 11.05 a.m. Firstly, teacher greeted the students by saying "Assalamualaikum Wr. Wb", the students stand up and answered "Waalaikumsalam Wr. Wb." The students also said "Good Morning, Miss", teacher answered "good morning, how are you today?", the students answered "I am fine, and you?", the teacher answered "I am fine too" and then she asked students to sit. After that, the teacher checked the students' presence list, calling students' name one by one.

The teacher began to open the material. The teacher told the students about the topic, namely recount text. The teacher did not directly enter on the material, but the teacher gave a little story about "Mr. Loyo and Mr. Maco" to motivate and stimulate the students' interest in learning English. After that, the teacher returned to the topic. The first, the teacher asked students' knowledge about recount text, then the teacher gave the example of recount text by telling her holiday experience in the beach. From the example, the teacher explained about the material of recount text. The teacher explained the definition, purpose, generic structure and language feature of recount text. In the middle of the explanation, the teacher invited the students to sang an english song related to the material then played little game and gave motivation so the students not bored.

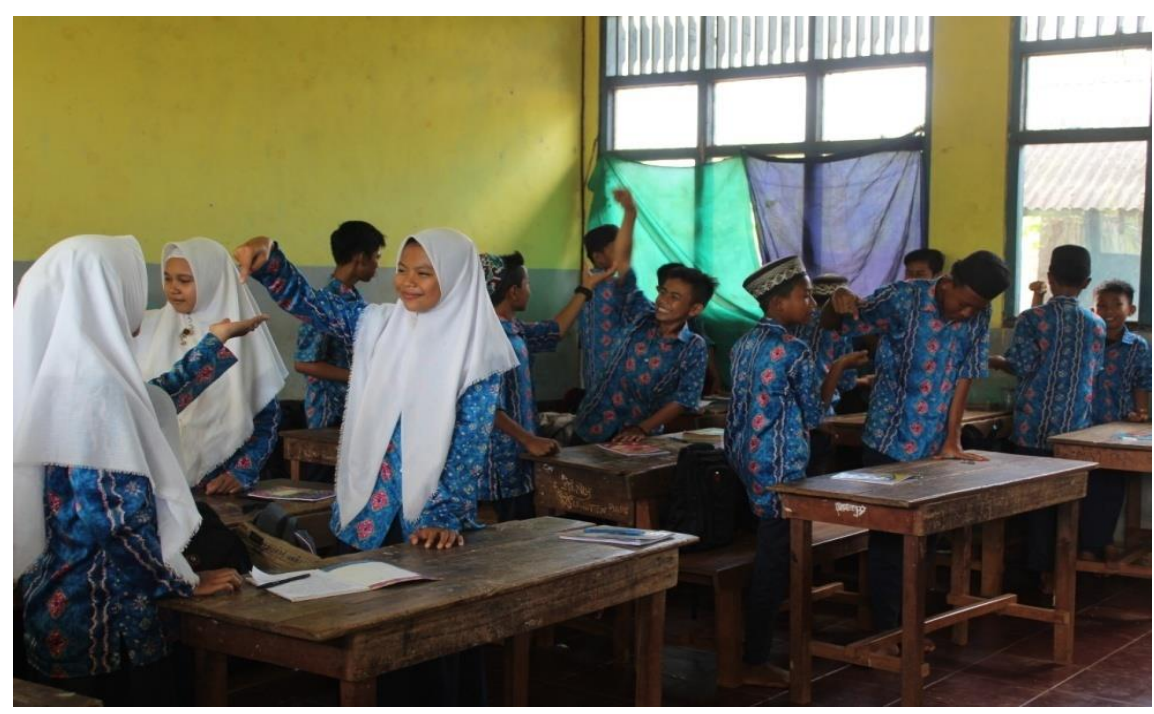

Picture 1. The students who were playing a game

From the picture 1 showed that the teacher invited the students for playing game together to exercise the students' concentration and raised the student's motivation in teaching-learning process at the class.

After that the students were required to write down the material on their books and they got explanation from the teacher and the teacher wrote an example of recount text from LKS book on whiteboard such as the following text: 
Fun With English Event

Hooray! We had fun with English in our school! We enjoyed this event on Wednesday, 17 September 2017 at Eka Saska Junior High School in Surakarta. We had waited for it since February 2017. So when the day came, we were really happy.

We played many games such as matching colors, matching pictures horseracing, running and finding and spelling bee. We had storytelling, too. All students from grade VII to grade IX joined fun with English, so there were 3 slots for the activities. We really had fun and we could practice our English. We also sang together about parts of our body, and twinkle-twinkle little star. Many prizes were given in this event. There were tickets from Pandawa Water Boom Solo Baru, some monev and many other merchandizes.

The teacher then asked students to read the text together and instructed them to analyze the generic structure or the language patterns. After that the teacher corrected students' answers and discussed together until the students understood. After the activities finished, the teacher asked the students if there was question about the material that they did not understand. And all of students answered "no". The teacher gave homework related to lesson today. There were 3 tasks and a text entitled "Hiking to Mount Penanggungan". Task 1 was changing the verbs in the text into the correct form, Task 2 was analysing the generic structure, and task 3 was the WH questions based on the text. Then the teacher divided the students into five groups. Every groups consist of four students. The teacher distributed the copies of text to each group. The teacher explained the instruction of tasks until the time was over. The teacher ended the lesson by saying salam.

b. The second Meeting

The second meeting was held on Friday 20th of July 2020 started at 09.45 until 11.05 a.m. The teacher entered the classroom by saying salam, then greeted the students in English and asked the students' condition. Then, the teacher checked the students' presence list, calling students' name one by one. After that the teacher asked the leader of the class to lead the pray section. Before starting the lesson, the teacher gave motivation to the students and reviewed the last lesson to stimulate the students' memory.

Then the teacher asked students about their homework about reviewing $\mathbf{5 + 1}$ Newspaper Organizer and submitted it to their teacher.

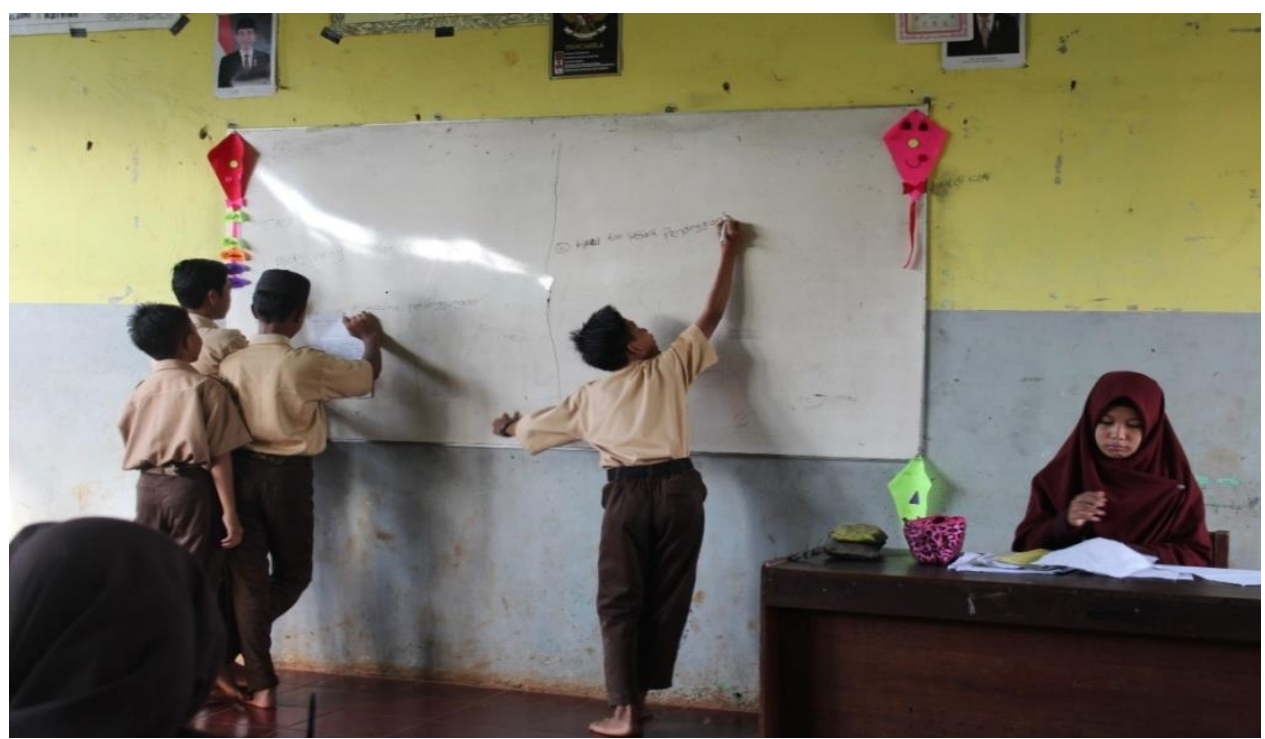

Picture 2. The students were writing their homework on the whiteboard 
Firstly, the teacher called a representation of each group to wrote their answers on whiteboard to display on the picture 2. There were two groups did not completed their homework so the teacher gave them punishment by singing an English song in front of the class. After that the teacher discussed the result of students' homework while repeated the explanation about the material of recount text which students still did not understood.

After the teacher discussed students' homework, the teacher continued introducing about $5+1$ Newspaper Organizer. 5+1 Newspaper Organizer is the WH questions in each column to help students organize the information from text. The WH questions are Who, What, Where, When, How, and Why. The teacher implemented 5+1 Newspaper Organizer as a strategy for developing students' reading skill. This strategy purposed to enable students to classify, identify and summarize information systematically from print materials.

In this meeting, the teacher used WH questions to make the implementation of $5+1$ Newspaper Organizer strategy went smoothly. For the example, the teacher gave a recount text entitled "First Day School' including 5+1 Newspaper Organizer, and then wrote the WH questions completely on blackboard so that the students could determine easily which information from text that related to the questions. The questions as follows :

a. Who is the main character in the text?

b. What does the text tell about?

c. Where was Risa's school?

d. When did Risa arrive at school?

e. How was the students' response about Risa?

f. Why did Risa move to the new school?

After that, the teacher drew the scheme of $5+1$ Newspaper Organizer on whiteboard while giving the explanation about it and how to fill it appropriate on each WH questions according to the text like the picture 3 .

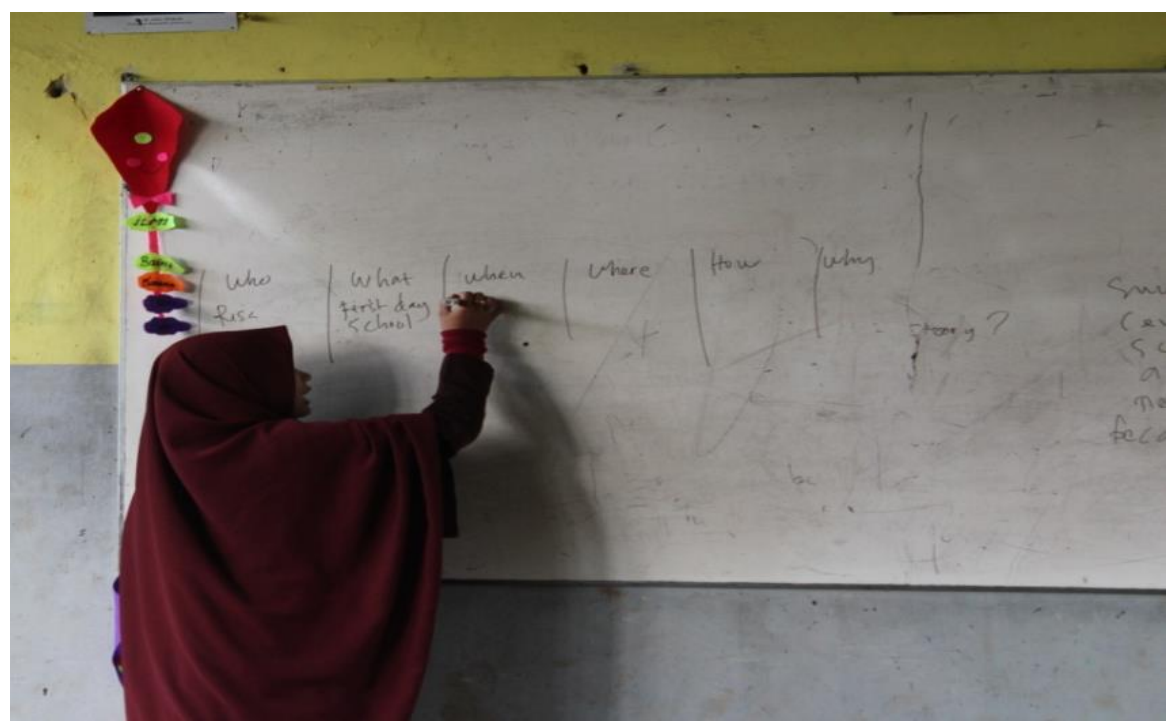

Picture 3. the teacher drew the scheme of $5+1$ Newspaper Organizer on whiteboard

The teacher was asking students to read the text first, and then modeling the ways to fill $5+1$ Newspaper Organizer strategy and giving the example such as following: 


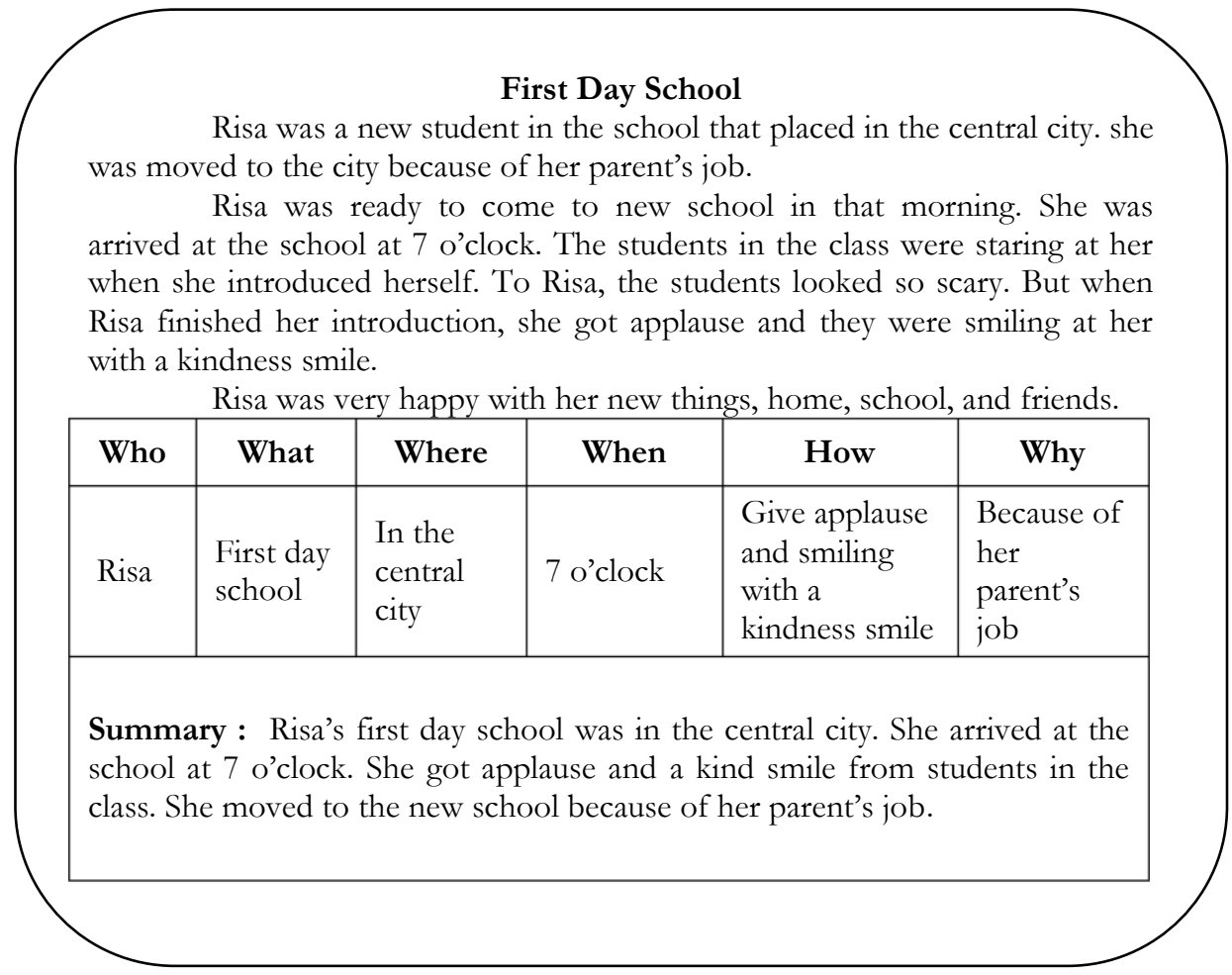

After the students understood the strategy, the teacher instructed them to practice. The teacher then divided the students into five groups that consisted of four members in each group. The teacher distributed the copies of recount text entitled "Go to the Market" including 5+1 Newspaper Organizer to each group. After that, the teacher wrote the WH questions completely, as following:

a) Who was involved in the text?

b) What did they do?

c) When did they go?

d) Where did they go?

e) How did they probably go?

f) Why did they go?

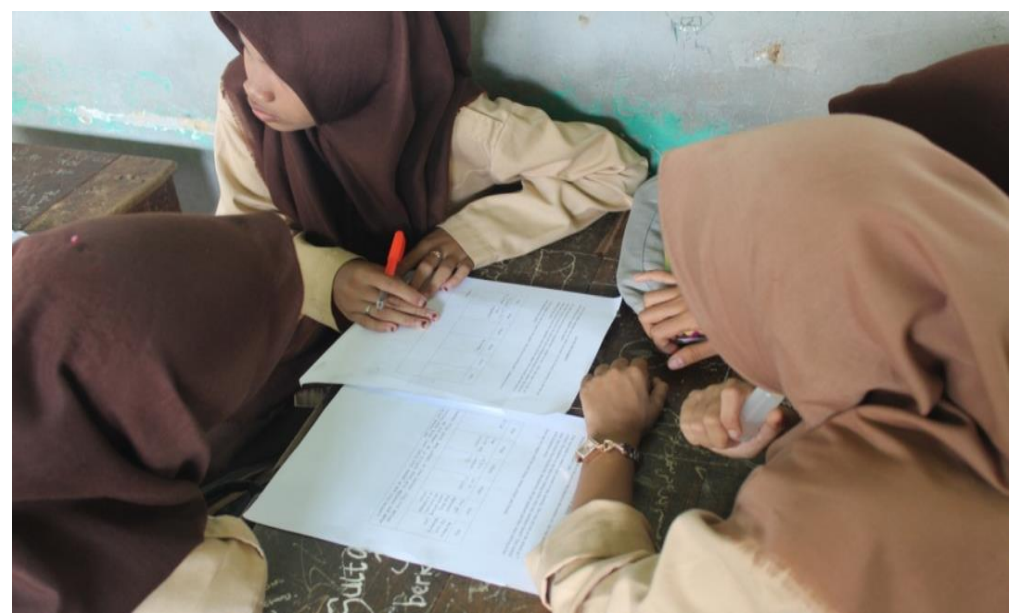

Picture 4. The students were discussing the task with their group

In the picture 4 showed that at the first, the group filled the blank of $5+1$ Newspaper Organizer strategy. Firstly, a few of students look confused about the questions and found difficult words to read 
and answer questions from text. The teacher monitored every group and gave the explanation once again so that they understood it.

It was about fifteen minutes to fill the blank of the $5+1$ Newspaper Organizer strategy. Because the time was over, the teacher assigned them to do it as the homework and it would be discussed in the next meeting. Before ending the lesson, the teacher concluded the lesson, then asked the chair of the class to lead the pray section. The teacher closed the class by saying salam.

\section{c. The Third Meeting}

This meeting was held on Friday 27th of July 2020 started from 09.45 AM until 11.05 AM. The teacher entered the classroom by saying salam then greeted the students in English "Good Morning, students". Then, the teacher checked the students' presence list, mentioned students' names one by one. After that, the teacher asked the leader of the class to lead the pray section. Before starting the lesson, the teacher motivated the students and reviewed the last lesson to stimulate the students' memory. Then the teacher asked students about the homework and submitted it to the teacher. After that the teacher started discussing the homework together at the class. Firstly, the teacher called a representative of each group to display their $5+1$ Newspaper Organizer's work. The teacher drew $5+1$ Newspaper Organizer on whiteboard, then the students filled it with their answer.

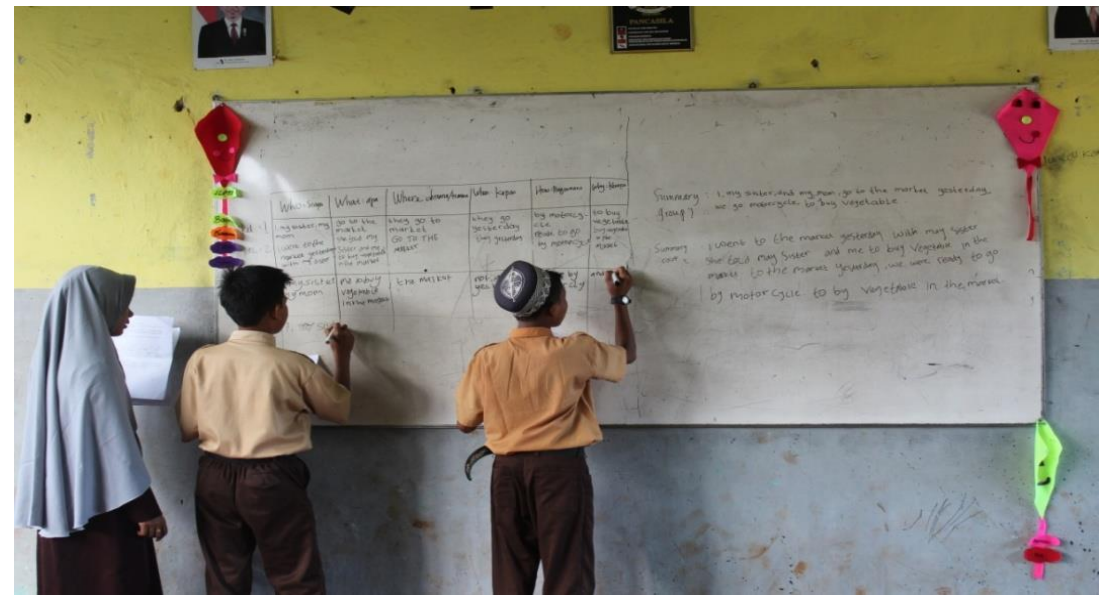

Picture 5. The representatives of each groups were writing their answers on the whiteboard

After all groups finished writing their answers on $5+1$ Newspaper Organizer strategy on the whiteboard, the teacher explained again to the students about the use of the strategy how to use the strategy and answer correctly from the text.

\begin{tabular}{|c|l|l|l|l|l|}
\hline \multicolumn{1}{|c|}{ Who } & What & Where & \multicolumn{1}{c|}{ When } & \multicolumn{1}{c|}{ How } & \multicolumn{1}{c|}{ Why } \\
\hline $\begin{array}{l}\text { I (the } \\
\text { writer) } \\
\text { and my } \\
\text { sister }\end{array}$ & $\begin{array}{l}\text { Go to } \\
\text { market }\end{array}$ & $\begin{array}{l}\text { The } \\
\text { market }\end{array}$ & Yesterday & By motorcycle & $\begin{array}{l}\text { To buy } \\
\text { vegetable }\end{array}$ \\
\hline $\begin{array}{l}\text { Summary : I with my sister go to the market yesterday by motorcycle to buy } \\
\text { vegetable. }\end{array}$ & & \\
\hline
\end{tabular}


The teacher also explained about the way of writing the summary in the $5+1$ Newspaper Organizer. The researchers observed them in using the strategy most of the group understood the strategy and were able to fill the column of the WH questions, but only one group still got confused to use it. The teachers asked another group to help the group explain the way of answering the questions and making the summary. Finally, all the groups looked so happy to learn it. After having finished correcting the students' homework, the teacher evaluated the process teaching and learning the reading skill by implementing $5+1$ Newspaper Organizer strategy. The teacher asked them whether they enjoyed learning and understood reading skills. Most of them stated that they were engaged and got a valuable lesson from reading texts. They said that vocabulary was the most challenge for them to understand the English texts and hard to make the summary in the last session of the strategy. Overall, the students looked enthusiastic to do the next task. The teacher explained once more regarding with the part of students' difficulties. The teacher suggested them to share the task with their members of the group so that their partners could do 5+1 Newspaper Organizer easier and went effectively.

After doing the exercise and evaluating the activity, then the teacher continued teaching a reading skill by introducing another text. After teaching it, then the teacher did the same way to practice another task. The teacher distributed the copies of recount text entitled "My First Flight Abroad" and commanded the students to understand the new text. After that the students had to do it with the same group previously and used the strategy and also completed it correctly. The teacher wrote the WH questions completely on whiteboard and asked students to read the text first before filling 5+1 Newspaper Organizer.

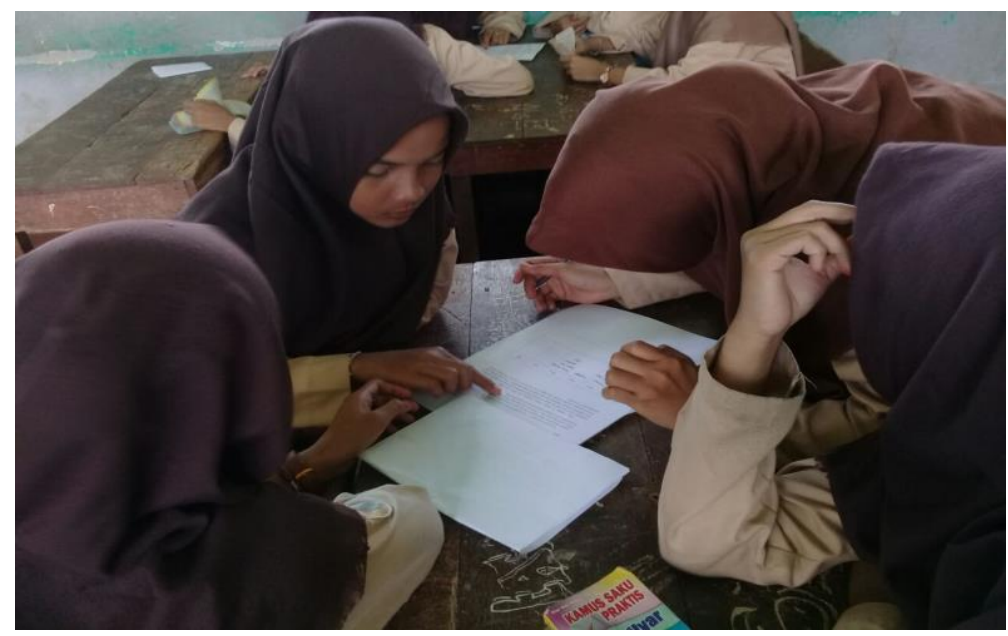

Picture 6. The female group was discussing the task

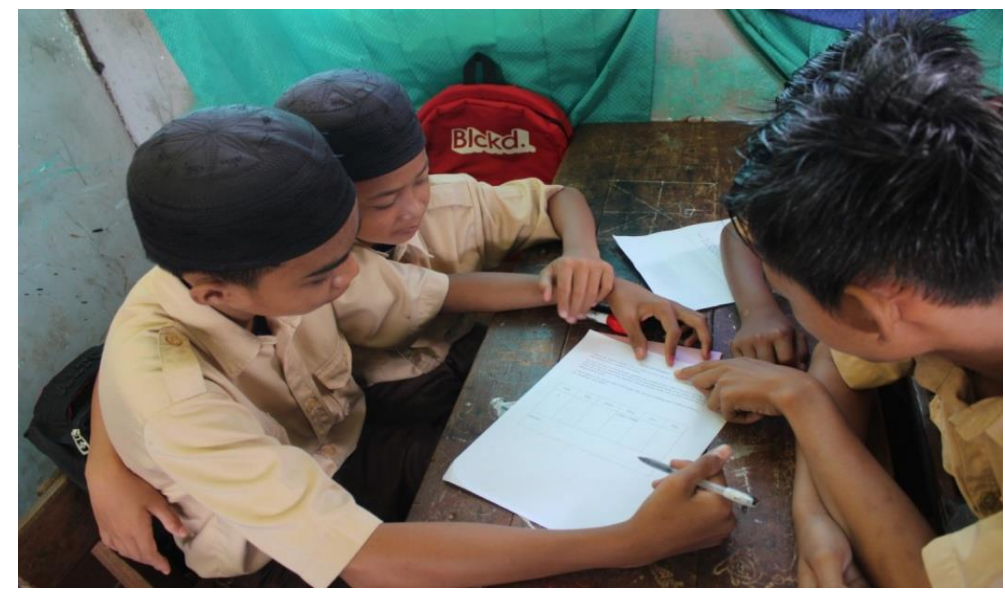

Picture 7. The male group was discussing the task 
The pictures 6 and 7 showed that they were discussing about the given tasks with the members of the group when they filled $5+1$ Newspaper Organizer. At this time they were actively sharing with their partners in doing the 5+1 Newspaper Organizer because they had already understood well what they were going to do. The teacher gave thirty minutes to complete the task. The teacher and researchers monitored every group to make it sure that they were answering with their members. After thirty minutes, the students submitted their works to the teacher. Because of the lesson time was limited, the teacher skipped students' presentation section and directed to discuss the result students' works.

The teacher drew 5+1 Newspaper Organizer on whiteboard, after that the teacher filled it with the correct answer while the teacher explained how to get the correct answer from text. Surprisingly, all groups had done well with the $5+1$ Newspaper Organizer perfectly. They were so happy and excited. Before ending the lesson, the teacher reminded students as always to learn it again at home. The teacher also reviewed about recount text and said that this was the last meeting of recount text lesson. The teacher asked the students how they felt when implementing 5+1 Newspaper Organizer in learning reading. They all said happy because this was a new activity for them to help the learning process of reading texts. After that the teacher ended the lesson with saying salam.

2. The Students' and Teacher's Responses When the 5+1 Newspaper Organizer Strategy Was Implemented at the Classroom

Implementing 5+1 Newspaper Organizer strategy was going smoothly but some of the students were confused at the beginning. It looked difficulty firstly when the teacher used the strategy in the classroom. After having been explained clearly by the teacher, students started understanding the procedures of using the strategy. They felt happy, active and enthusiastic to learn reading skills because they could work collaboratively and share the ideas with their teams to find the explicit and implicit information of the text. Moreover, they also were able to identify kinds of difficult words and reminded the words of the text easily. It was proved by one of the students said in the interview

I was very lucky and happy to learn with $5+1$ newspaper organizer because I got easy to do the reading task collaboratively

Another student also stated that:

This strategy helped me understand the content of certain text easily because of using WH questions, I felt easy to find the conveyed information of the texts.

Most of the students responded to the strategy positively and they could understand the given text easily by the teacher. This strategy also eased the teacher to make learning activities alive at the classroom. The teacher believed that it is a useful and valuable to teach reading skills and help students develop this skill better and better than before. As stated by the teacher in Indonesian langiage in the interview

By implementing this strategy, the class was so enjoyable and interesting and also interactive. The students were interested in reading English texts and engaged to find more information of the texts.

\section{Conclusion}

Based on the findings, the researchers conclude that implementing 5+1 Newspaper Organizer as a classroom strategy is a good way for developing students' fluent reading. 5+1 Newspaper Organizer is a tool that help students to classify and organize the information in a text. In teaching learning process, the teacher used recount text as the learning material and implemented $5+1$ Newspaper Organizer at the second and third meeting because the first meeting used by teacher to introduced the material and $\mathrm{WH}$ questions. The teacher divided students into groups and then distributed the copies of recount text including 5+1 Newspaper Organizer to each group. The implementation of $5+1$ Newspaper Organizer as a classroom strategy for developing a fluent reading 
was going interactively because the students discussed with their groups and then together with the teacher discussed the result of 5+1 Newspaper Organizer. The 5+1 Newspaper Organizer strategy leads the students to be more active for discussing and make the students develop their reading skill. The students' and teacher's response looked happy to use it at the class because it is effective to help students learn reading and valuable for the teacher to achieve the expected goals of teaching.

\section{References}

Abadiano, H. R, \& Turner, J ( 2005). Reading fluency: the road to developing efficient and effective readers. The New England Reading Association Journal, 41(1), p 51-52.

Anderson, N. (2003). "Reading” in practical English language teaching reading. David Nunan. (ed.). New York: Mc Graw Hall.

Apsari, Y, \& Yana (2015). Teachers' techniques and problems in teaching Reading. Jurnal Ilmiab UPT P2M STIKIP Siliwangi, 2(2), p 230.

Bellanca, J. (2007). A guide to graphic organizers: helping students organize and process content for deeper learning----$2^{\text {nd }}$ ed. United Kingdom: Corwin Press.

Barthimeus, Yakob S (2011). Improving students' reading comprehension through MURDER technique (A classroom action research at the eighth grade students of SMP Negeri 1 Kendari in the academic year of 2010/2011). Unpublished M.Ed Thesis, Sebelas Maret University.

Crystal, D. (2003). English as a global language (2nd Volume). United Kingdom: Cambridge University Press.

Dalman. (2013). Keterampilan Membaca. Jakarta: PT RajaGrafindo Persada.

Giri, F. (2003). Implemented small group discussion strategy to teach simple present tense in SLTP 1 Sukasada. Jakarta: Jakarta Press.

Grabe, W. (2009). Reading in a second language: moving from theory to practice. Cambridge: Cambridge University Press.

Harmer, J. (1998). How to teach English. Cambridge: Pearson Longman.

Juel, C. (1988). Learning to read and write: A longitudinal study of 54 children from first through fourth grade. Journal of Educational Psychology, 80 (4), p437-447.

Kuswari, Usep. (2010). Membaca intensif. http://www.file.UPI.EDU./ (accessed on August 3th, 2018).

Marzuki, A.G. (2016). Developing reading skill of islamic education department students through guided reading. Paedagogia: Jurnal Pendidikan, 5(2), p237-238.

Mawarni, Lega. (2015). The students' ability in comprehending report text at the ninth grade of SMPN 2 Alalak school year 2014/2016. Unpublished Thesis. Banjarmasin: Uniska.

Moleong. (2010). Metodologi penelitian kualitatif. Bandung: PT. Remaja Rosdakarya.

Nuttal, (1982). Teaching reading skills in a foreign language. London: Heinemann Education Book ltd.

Rivers, W. M. (1981). Teaching foreign language skills. United States: The University of Chicago.

Sanjaya, W. (2006). Strategi pembelajaran berorientasi standar proses pendidikan. Jakarta: Kencana Prenada Media Group.

Spratt, M., A. Pulverness, \& M. Williams. (2005). The TKT (teaching knowledge test) course. Cambridge: Cambridge University Press.

Sugiwati, F. 2008. Improving students' reading comprehension ability through 'WH-questions" technique at the eighth year of SMPN 28 Bandar Lampung. FKIP. Unpublished Script: Lampung University Press.

Sugiyono. (2016). Metode penelitian kuantitatif kualitatif dan R\&D. Bandung: Alfabeta. 
Tarigan. H. G. (1979). Membaca sebagai suatu keterampilan berbahasa. Bandung: Angkasa.

Tohirin. (2013). Metode penelitian kualitatif dalam pendidikan \& bimbingan konseling.

Wallace, C. (1992). Reading. Oxford University Press 